\title{
Nature as a Healer against Anthropocentric Disposition in Anita Desai's Fire on the Mountain
}

\author{
Raj Kumar Baral \\ Lecturer, Tribhuvan University \\ Email: baralraju@gmail.com
}

\begin{abstract}
In her novel Fire on the Mountain, Anita Desai, by making her characters burn the images related to the ill and superstitious law of the anthropocentric world, intends to revere the natural world, which for her possesses healing capacity to revive the dying identity. Nanda Kaul, the protagonist and her great-granddaughter, finds pleasure with nothing else but with the barrenness, stillness, calmness and voice of silent breeze and music of nature itself. The fresh air of the quiet breeze in the naturally painted house wins the heart of the protagonist over the stale air of the electric fan in the artificially painted house. By utilizing theoretical ideas of ecofeminism in communication with deep ecology, the article concludes that the proper tribute to nature is possible when hierarchies between human and non-human blur and biocentric world view exists.
\end{abstract}

Keywords: anthropocentrism, biocentrism, apocalypse, ecological consciousness Anita Desai's novel Fire on the Mountain shows how anthropocentric laws fail and how nature functions as a healer against those human-induced oddities. In line with Paul Taylor, who argues, "Humans and animals share the earth, and should live equally and harmoniously" (75), Desai prioritizes the subtle sense of biocentrism over the apocalypses of the anthropocentric and patriarchal Indian society. Organic relation among the botanical, zoological and human beings follow the philosophy of pantheism that equalizes all living and non-living as the part of the same nature and root of origin.

Nanda Kaul, the protagonist, moves away from the mainland and is drawn back to the hills of Carignano for privacy, solitude, and tranquillity. As the head of a large family and vice-chancellor's wife, she lives a hectic and troubled life. She longs for privacy all through her life, and at last, she gets it in the hills of Kasauli. The expression, "What please[s] and satisfi[es] her, so here at Carignano, [is] its barrenness" (4) shows her satisfaction and feeling of happiness with nothing else but with the barrenness and stillness of the mountain.

Desai wrote this novel in post-independent India when anthropocentrism and, more significantly, male activities were hierarchically in a superior position. Hierarchy of nature and culture compares male to be civilized and cultured but female as the 
dominated group of the society and nature is ruled by so-called cultured and civilized males. In her book Theorising Patriarchy, Sylvia Walby asserts that patriarchy is "a system of social structures and practices in which men dominate, oppress and exploit women" (20). And anthropocentrism being androcentric assumes that they can do whatever they like in nature, and nature has to tolerate the domination and to remain silent (Daniel 1). Male can destroy nature, enjoy by doing the destructive activities on earth and female is compared to earth, and they should be silent, submissive and introvert. Desai depicts women characters' struggle to seek their identity in a biocentric/ecocentric world of nature which was not possible under the evil laws of anthropocentric society.

In its early part, this novel depicts the apocalypses of the anthropocentric world and its harmful effects upon the psychology of the marginalized group of the society and then it arouses the sense of the value and importance of biocentrism. Expressions like "That house, his house, never hers" give the hints (18). Kaul runs dutifully to the perfect house for her husband and family but to which she never belongs. It shows the hierarchy of centre and margin in an anthropocentric and androcentric world, where the male is placed at the centre and the female at the bottom and to follow the rules made by the elitist and have no right to revolt against. Desai rejects such anthropocentric culture, where the binary between centre and margin collapses and the philosophy of every living being has equal right exists.

The elitists make the rule of society and culture, so it is not easy to change them. Desai disagrees with this class of society because it never changes its thought; instead it turns aggressive and does not eliminate the evil of the anthropocentric world. As the loving mother of every origin, nature is equal to every creature and species, so nature itself changes its rule like the seasonal change of day into night and night into days. Ramlal, in the novel, says:

This is how forest fires do start. I can't tell you how many forests fires we see each year in Kasauli. You can see how many of the trees are burnt, and houses too. Hut? It was a beautiful cottage. An English Mem lived there. It was burnt down in a forest fire. All that drygrass will set on fire. (53-54)

This extract shows the changing rule of nature to replace the old and loaded images of the earth to a new one as it has the power to regard every creature, botanical and zoological images of nature as equal. There is no need to struggle and no violence in nature to create a space for the new one. 
True to Barry Commoner's argument, "Everything is connected to everything else" (33), Desai depicts the friendly relation between and among every species, botanical, zoological, and geographical images of nature. There is no violence and murder of even a small creature like moth, insect, grasshopper, flies, spider, snake and so on, rather their presence in front of the protagonist Nanda Kaul and her great grand-daughter Raka diverts the traumatic psyche caused by domestic violence into pleasure. Desai writes:

Kaul fancied and she could merge with the pine tree and be mistaken for one. To be a tree no more and no less was all she was prepared to undertake. What pleased and satisfied her so, here at Carignano, was its barrenness. This was a chief virtue of all Kasauli of course- Its starkness. It had rocks; it had pines. Yes, there were some apricot trees close to the house. There were clumps of iris that had finished blooming. (4)

Human beings' connection with the botanical images and the non-human creature of the nature imparts the sense of pleasurable moment to the characters' rather than in the anthropocentric world. Therefore, nature is the healing force or medicine for the wounded psyche of the traumatized and marginalized group of society.

For hundreds of years, India was under the colony of Britain. Westerners seize the Indian natural resources and make their land for shelter and hide the aboriginals' realities. They destroy the natural riches of the pastoral wilderness. Urban expansion, in turn, seems to produce an excess of noise, pollution, overcrowding and social problems. The middleclass men like Mr. Kaul function as compradors who imitate Western culture and impose their authority upon others and regard themselves as superior, powerful, and elitist. In this backdrop, Desai critiques "the tendency of wearing a false mask" and points out nature as the only source of solace (Baral and Karki 11). Desai wishes:

She would be a charred tree trunk in the forest, a broken pillar of marble in the desert, a lizard on a stone wall. A tree trunk could not harbour irritation, nor a pillar annoyance; she would imitate death, like a lizard. No one would dare to rouse her. Who would dare? The parrot dared. A sudden quarrel broke out in the tree-tops; for a moment they all screamed and scolded together, then shot off like rockets, scattering pine nuts, disappearing into the light, disintegrating in the heat. (23)

Desai, in these lines, shows that the broken pillars of marble have an identity in the desert, lizard on the rock, cicadas and pine tree has an identity on the barrenness and stillness of the mountain, in the same way, the protagonist Nanda Kaul tries to live her 
life being attached with nature. For her, the bio-centric world of nature only provides equal identity to all species evoking ecological consciousness.

Arcadian Discourse is the significant typology of the critical environmental discourse of "Back to Nature movement" in the twentieth century. Desai depicts the role of the characters in her novel to show her dislike of the luxurious product of modern technological advantages and instead leave everything back to nature, to their origin, to the earth at the peacefulness and barrenness of and stillness of Carignano Mountain. Desai asserts:

Nanda Kaul asked to be left to the pine and cicadas alone; she wanted no one and nothing else. Whatever else came, or happened here, would be an unwelcome intrusion and distraction. Everything she wanted here, at Carignano, in Kasauli, on the ridge of the mountain, is this quite house. (3)

Nature has the power of an ongoing process of creation, revealing the progressive unfolding of divine design. It has a kinetic force by which nature was ever at work, creating and destroying in a translating matter, out of one beautiful form into another. Nanda Kaul describes:

Look at the hydrangeas, beaten down by the rain, said Nanda Kaul, her voice natural once more, and rounded with relief and pleasure. The Thunder galloped across the roof, chasing the fleecy cloud and lighting rain. Look how the rain brings out their colour they are blue again. (86-87)

Nature has the power to create, destroy the old to replace with new, and complete, recreating, shaping, and reordering the natural world. In this issue, John Muir writes, "Nature is ever at work building and pulling down, creating, and destroying. Keeping everything whirling and flowing, allowing no rest but in rhythmical motion chasing everything in endless song out of one beautiful form into another" (31). In this way, the eternal flux of nature constitutes a fundamental principle for Muir, explaining the formation of the landscape over time, ice changing into water, lakes to meadows and mountains to plains and grounding his belief in nature that is alive and continually changing. Big heart of the earth keeps everything in a joyful and rhythmic motion. The characters of the novel, Nanda Kaul and Raka, cannot find that joyous experience in society's statuesque rule. The Carignano that affords the best bed-chamber with plenty of wind that originates from pine and apricot tree is sufficient for one to sleep. Desai describes:

Inside, the flies, outside, the cicadas. Everything hummed, shrilled, buzzed, and fiddled till the strange rasping music seemed to materialize out of the air itself 
or heat. Nanda Kaul lay on her bed, absolutely still, composing her hands upon her chest, shutting her eyes to the brightness of the window, watching for the cool stir of breeze in the late afternoon to revive her. (22-23)

Nanda Kaul fidgets with the louder and thundering earth music of the modern technological development but pleases with the music produced at Carignano Mountain; two ways of music inside the flies and outside the cicadas.

Desai shows the power and energy of nature that nature's annual festival commemorates a farewell programme for the old and aged or dry objects or beings and welcomes the new plants, flowers, and trees. These sentences, "It is a forest fire. A big fire it seems. Oh there's always a forest fire at this time of year" (74), describe how old things are left behind and new ones are welcomed. Burning fire on the mountain is the farewell ceremony to create space for the newcomers and newly originating plants, flowers, and trees. Desai, writing in an assured and witty style, draws upon the intimate familiarity with the countryside around the mountain Carignano to show how seeking out and enjoying wild fruits and learning to see the colures of the autumn landscape can connect one with the vitality of the natural world. "Raka had come out into the wet grass early in the morning to eat apricot before breakfast" (65). The character Raka does not frighten to come out alone early in the morning and goes to collect the wild berries because that is the lap of mother, nature, and Earth God.

Nanda Kaul's journey to nature is the journey from culture to nature. Rule-bounded androgenic culture discards women as nothing or no man's land; they do not have their own property in such society, but nature blurred such hierarchy and honours women as goddesses, mothers, or Earth in a bio-centric world. Nanda Kaul "reads Gogol's Dead souls; a Waley's translation of Chinese poem, a book on Indian birds by Salim Ali" (62). Here Kaul tries to go back to her origin where she originated: India; India is her origin, and there is an eternity of soul in the origin that is earth and earth is nature. In this way, she realizes the value of her identity vis-à-vis nature. She contemplates:

Awkward Things, Things that lose by being painted, Things that gain by beings painted pines, pink cherry blooms, yellow roses Autumn Fields, Mountain villages and paths, cranes and deer's, Herbs and shrubs, insects and found herself spinning out of lists of her own. (28-29)

The novel shows the rebirth of the creative power of the characters on the lap of nature which, on the contrary, is dead in the anthropocentric society. It depicts the identity crisis of women in a dominant culture of men as they are represented as others and no man's land in the male-centred community, they are living the hell-like life, and no space has 
been given to them, but in the biocentric world they are regarded as heavenly creatures as novel presents:

Nanda Kaul paused under the pine tree to take in their scented sibilance and listen to the cicadas fiddling invisibly under the mesh of pine needles. She did not want the postman to stop at Carignano. She asked to be left to the pine and cicadas alone. She hoped he would not stop. She stopped now to pick up a bright apricot from the short, dry grass. (3-4)

This shows the freedom of Nanda Kaul in the lap of nature, where she does whatever she likes and wanders as a nymph wanders freely in heaven. Even the gorge, ravine, barrenness of the mountain is like an Eden to the protagonist. Nanda Kaul's desire to fly like eagle and birds in the sky and trying to merge with the pine trees and Raka's joy of shipwreck in the wind of pine, cicadas and apricot trees visualizes the eco-critical concern in the novel. Moreover, the biocentrism in the novel ruptures the hierarchy of centre and margin, men and women prevailing in the anthropocentric world.

Donald Worster writes environmental histories studying the reciprocal relationship between human and land, considering nature not just as a stage upon which the human story is acted out, but as an actor in the drama (27). So, nature itself changes its history as the seasonal change to create new upbringing of botanical and zoological images.

In this way, the earth-centred approach in the novel assumes the earth as an Eastern god or Earth Goddess. As Eastern theology of Hinduism regards the female triad as deities Parvati, Durga and Kali. The line, "She was grey" (4), means to say that Nanda Kaul, the protagonist of this novel, is a reincarnation of the goddess Kali. Nanda Kaul might also assimilate to the Goddess Durga of the Hindu Vedic pantheon, as she was an inaccessible leader of the mothers. Female deities freely wander to the Carignano Mountain and kill and destroy the unwanted evils of nature that are disgusting to them. Kali also kills all her victims and enemies in the battle, as eastern mythology says. Raka is further described as a "perceptive child" (46). As Kali wanders to the ravine, hills, and mountains at the darker night, Raka also usually goes out roaming on her own in the Kasauli landscape of stone and the bushes till dusk. Raka meant the moon. However, Raka is not compared to the round, calm, radiant face of the moon here, but rather implicitly to the darker side of the moon, and therefore to the darker aspects of the goddess, that is to Kali, the black one.

Since ecology studies the relation between species and habitats, eco-criticism must see its complicity in what it attacks. All writers and their critics are stuck with language, and although we cast nature and culture as opposites, they frequently mingle like water and 
soil in a flowing stream. The novel shows human beings' mingling with biological, zoological, and botanical images of nature. Non-human images of nature like the pine tree, cicadas, apricot tree, flowers like lilies, hydrous and the small zoological objects like insects, moths, butterflies, grasshopper, lizard, are the source of generating happy life to the characters which soothe the traumatic experience of the society.

Zoological creatures of nature are friends with the human beings in the novel that show the evolution of human beings primarily from the non-human creatures of nature suggests that human and non-human beings are friends to each other are getting birth by the same mother Earth.

Desai shows the automated system of nature: Lilies bloom and fade; sometimes the rain destroys the flowers; sometimes thunder and the natural wind blows and burns the dry grass of the Kasauli Mountain. Such a generating, creating, and destroying nature, commemorating the farewell ceremony to the old images of nature to vacant the place for the newly uprooting images, really romanticizes the rule of its history.

By unfolding the regenerating nature of history, this novel shows organicity among human beings and non-human beings on the lap of nature. Harmonious pose and relation generate the art of imaginative power to the characters, and the destructive activities of the zoological objects remind the traumatic experience of the anthropocentric world. The line "She watched the white hen drag out a worm inch by resisting inch from the ground till it snapped in two. She felt like the worm herself, she winced at its mutilation" (21) reminds Nanda of the painful and traumatic experience when she was severely injured psychologically. But the lines "Monkeys and languor swung with boastful grace, playing Tarzan in the trees. Clapping their hands to their mouths, they hallooed like cinema heroes of the wilds. Rakha and Nanda Kaul went downhill, laughing at a quick pace refreshed" (59) depict the romantic moment and joyous situation of the non-human beings that romanticizes the human beings and pacifies their traumatic psyche.

\section{Works Cited}

Baral, Raj Kumar, and Nitesh Chandra Karki. "What is inside the Mask: White or still Black? A Post-Colonial Musing on Wole Soyinka's The Interpreters." International Journal of English Literature and Social Sciences, 5(6): 2000: 113-2123.

Commoner, Barry. "The Environmental Crisis." The Closing Circle: Man, Nature and Technology. Alfred Knopf, 1992. 11-13.

Desai, Anita. Fire on the Mountain. Allied Publishers, 1977. 
Muir, John "My First Summer.” Imagining Wild America. University of Michigan Press, 1937. 30-36.

Pérez Marina, Daniel. Anthropocentrism and Androcentrism: An Ecofeminist Connection. Sodertorn University, 2009.

Taylor, Paul W. Respect of Nature: Environmental Ethics Introduction with Readings. Ed. John Benson. Routledge, 2000.

Walby, Sylvia. Theorising Patriarchy. Basil Black Well, 1990.

Worster, Donald. The Wealth of Nature: Environmental History and Ecological Imagination. Oxford University Press, 1993. 